\title{
Knowledge Sharing in Industrial Associations and Science and Technology Parks
}

\author{
Danielly Oliveira Inomata ${ }^{1,2(凶)}$, Eric Costa ${ }^{2,3}$, Solange Mazzaroto ${ }^{2,4}$, \\ Cláudio Santos ${ }^{2}$, Ana Cristina Barros ${ }^{2}$, António Lucas Soares ${ }^{2,3}$, \\ and Gregorio Varvakis ${ }^{1}$ \\ ${ }^{1}$ Federal University of Santa Catarina, Florianópolis, Brazil \\ inomata.danielly@gmail.com, grego@egc.ufsc.br \\ 2 INESC TEC, Porto, Portugal \\ \{eric.m. costa, solange.mazzaroto, claudio.a. santos, \\ acbarros\}@inesctec.pt \\ ${ }^{3}$ Faculty of Engineering, University of Porto, Porto, Portugal \\ als@fe.up.pt \\ ${ }^{4}$ Faculty of Arts, University of Porto, Porto, Portugal
}

\begin{abstract}
Knowledge management practices are used in collaborative networks promoting innovation in order to share critical knowledge among network members towards improving organizational results. This paper proposes to explore the channels and practices for knowledge sharing in collaborative networks, by means of an exploratory multiple case study carried out in two types of collaborative networks: (i) industrial associations; and (ii) science and technology parks. Empirical evidence has been collected from interviews with managers of the collaborative networks and of organizations participating in the collaborative networks. The contribution of this paper to the knowledge management literature is twofold: (i) it provides a characterization of the channels and technology used for knowledge sharing in collaborative networks based on empirical evidence and (ii) it describes knowledge sharing practices used among organizations to foster new forms of connectivity between groups and individuals.
\end{abstract}

Keywords: Knowledge sharing · Collaborative networks · Industrial associations $\cdot$ Science and technology parks

\section{Introduction}

Science and Technology Parks (STPs) have an impact in the economic growth and regional development [1, 2]. Companies in environments of STPs can benefit from the knowledge spillovers resulting from the research, ideas and experiences from both universities and research centers [3] or by the contact with other companies located in the park [4]. Industrial associations (IAs) also act as facilitators to provide critical knowledge for their associated companies, which can result in innovation and competitive advantages [5].

The discipline of Knowledge Management (KM) is concerned with the organizational knowledge as a process coming from individuals in a collectivity, providing benefits to individuals, employers, communities of practice and organizations [6]. 
The challenge of this paper is to identify practices for knowledge sharing in networked innovation environments, such as STPs and IAs, contexts that to the best of our knowledge are still unexplored in the literature [7]. Previous research is related with how the process of KM is carried out in small and medium enterprises [8, 9], the dynamics of knowledge creation in inter-organizational cooperative networks [10], and the knowledge transfer in collaborations between companies from developed and underdeveloped countries [11]. This paper is focused on understanding knowledge sharing practices in STPs and IAs.

Knowledge sharing is described as a process that involves source, channel, message, destination and context $[6,11]$. In this paper, the knowledge sharing in networks is defined as the behavior of individuals to pass along what they know to people with whom they interact (e.g. by means of product development, resource sharing, etc.), and vice-versa. Therefore, it is a mutual process of individual knowledge sharing to create a new knowledge in collaboration, where actors use multiple resources to this end, such as formal and informal channels, tools and technologies.

Regarding knowledge sharing in collaborative networks (CNs), previous research has been carried out in contexts such as internationalization of SMEs [12], services for industrial apprenticeship [13], socio-semantic collaborative platforms [14], social capital [15], or supply chains [16]. However, there is still a need to study knowledge sharing processes in different CNs and contexts, such as STPs and IAs. This gives room to the following research questions:

- How knowledge sharing practices occur among network members in IAs and STPs as collaborative networks?

- What have been the impacts for knowledge sharing?

Therefore, this paper proposes to explore the practices and channels for knowledge sharing in STPs and IAs, two different types of CNs. To this end, one STP and three IAs were selected to perform an exploratory multiple case study. The data sources used were semi-structured interviews with managers of the CNs and of organizations participating in these four CNs. This paper contributes to the literature of KM, with specific focus on the knowledge sharing process, as well as to the scientific knowledge of CNs. First, based on empirical evidence, it provides new insights about the channels and practices of knowledge sharing used in STPs and IAs. Moreover this study discusses how the establishment of CNs can facilitate knowledge sharing between companies associated with IAs, as well as startups incubated in STPs.

\section{Literature Review}

\subsection{Collaboration and Collaborative Networks}

The widespread concept of collaboration means "to work together towards a common goal" and involves mutual engagement of participants to solve problems in a process of sharing risks, resources, responsibilities and rewards [17]. In a context of inter-organizational networks, collaboration is considered as the process where two or more organizations perform tasks together to obtain collective results [18]. Therefore, 
in a collaboration process, autonomous actors interact with each other through formal and informal negotiations, creating together rules and structures to govern their relationships, as well as to define how they will act and make collaborative decisions [18].

Collaboration clearly impacts business performance and is recognized as a mechanism to increase competitiveness and, in many cases, the survival of companies [19]. So, many organizations are joining efforts using different collaborative models by joining complementary skills and capabilities, gaining new competitive advantages to deal with global market dynamics and environments [20]. Parung and Biticti [21] consider that the most important objective for establishing a collaboration is to become sustainable and create benefits for stakeholders in a competitive environment.

Many companies and organizations are forming collaborative networks with their partners for different purposes, such as to share risks and benefits [21] or to obtain important information and knowledge for their activities [12]. Camarinha-Matos and Afsarmanesh [22] define collaborative networks (CNs) as networks of organizations formed by different and autonomous entities that are geographically distributed and that are heterogeneous regarding operating environment, culture, social capital, and goals. Most of the times, interactions and collaborative processes in CNs are supported and mediated by information and communication technologies [18, 22]. Organizations can form different types of networks, such as supply chains, virtual enterprises, clusters or extended enterprises [21]. Despite the existence of many network forms, CNs differ in the fact that collaboration is "an intentional property that derives from the shared belief that together the network members can achieve goals that would not be possible or would have a higher cost if attempted by them individually" [22].

In this paper, two different types of CNs are considered: (i) industrial associations (IAs); and (ii) science and technology parks (STPs). We consider an IA as being both an organization that represents different companies of a specific industrial sector (sectoral IA) or an entity that act as an intermediary within a multisector network of companies in a specific area of activity (multi-sectoral IA). In both cases, membership for companies is voluntary and IAs develop an effective communication between their associated industrial firms with local governments [23]. Nevertheless, one of the main focus of IAs is to promote and improve collaboration among network members [24]. Regarding STPs, they are characterized by the physical facilities with buildings, laboratories, etc., combined with managerial support and with close access to research organizations [7]. Thus, they consider not only the university knowledge transfer for companies, but also the demand from these companies to the development of more effective knowledge to meet market needs [25]. Although there is no common definition of STPs, most of the literature emphasizes the importance of three dimensions [7]: (i) the physical location is in close proximity to a research institution; (ii) the knowledge or high-tech business is the core business; and (iii) there is a specialized managerial function to help the startups with new businesses (incubation).

\subsection{Knowledge Sharing in Collaborative Networks}

Knowledge is information that is combined with experience, interpretation and reflection, representing a high value form of information to be applied for making 
decisions or taking actions [26]. Knowledge sharing is considered as one of the more critical components for the KM success [27] and is the process when individuals exchange mutually tacit and explicit knowledge, creating new knowledge in collaboration [28]. Therefore, new knowledge is incorporated in an organizational knowledge only when is shared and assimilated using routines, documents and organizational practices [29]. This knowledge can be incorporated through action, contextualized in practice and subject to actors' interpretations [26].

In CNs, the knowledge sharing process happens at the individual and organizational levels. The individual knowledge is used to develop the organizational knowledge base but this organizational knowledge is not just the sum of the individual knowledge [30]. Technologies, techniques, and people create unique patterns of interactions to form the organizational knowledge. This knowledge is difficult to imitate by other organizations since the interactions are developed and shaped by the unique history and culture of organizations from a specific CN [30].

The ideal situation is obtained when network members share critical knowledge, exploit expertise and use resources for collective benefit [31]. Huang and Cummings [32] define critical knowledge as "the most influential information, know-how, or feedback that contributes directly to task outcomes". Cormican and Dooley [31] consider that an immediate access to the latest information, which includes information from external sources, allow organizations to reach a critical competitive edge.

Many practices can be adopted by organizations for the process of knowledge sharing. The Asian Productivity Organization (APO) presents a practical KM guide where an extensive set of knowledge sharing practices are indicated to be used by organizations [33], such as peer assist; communities of practice; collaborative physical workspaces; knowledge cafes; taxonomy; knowledge bases; social networking services; voice and VOIP; knowledge clusters; collaborative virtual workspaces; knowledge portal; mentor/mentee. This paper shows the knowledge sharing practices used between network participants of STP and IAs.

\section{Research Methodology}

Case research was used in this study because it enables an empirical description of a contemporary phenomenon within its real-life context [34]. Specifically, an exploratory multiple case study was used to explore the channels and practices of knowledge sharing in different types of CNs, i.e. IAs and STPs. The unit of analysis in this study is the collaborative network. Table 1 characterizes the case studies of this research.

Table 1. Case studies

\begin{tabular}{l|l|l|l|l}
\hline ID & Type of CN & Area of activity & Network members & Interviews \\
\hline STP & STP & (i) Technologies & 84 & 9 \\
\cline { 3 - 5 } & & (ii) Biotechnologies & 17 & \\
\hline IA1 & IA (sectorial) & Aerospace industry & 34 & 4 \\
\hline IA2 & IA (multi-sectorial) & Production technologies & 103 & 6 \\
\hline IA3 & IA (multi-sectorial) & Innovation & 367 & 4 \\
\hline
\end{tabular}


These cases were selected by convenience sampling [35], i.e. access to data and contacts with companies was easier. Empirical evidence was collected using semistructured interviews with managers of the CNs and of organizations participating in these four CNs. The aim was to obtain a good sample representing different types of organizations and CNs. Although the study included only one STP, two areas of its activity were analyzed, in a total of nine interviews. Regarding the IAs, one sectorial and two multi-sectorial were selected. Although also being multi-sectorial, IA2 was considered in this study since it presents a different type of association. In this case, different types of organizations were interviewed, such as technology providers, research institutes and universities, industrial associations, and end users.

Different management roles of the member organizations were interviewed, such as Presidents, CEOs, CFOs, Administrators, and people from technical departments, all of them with an active role in CNs. At the beginning of the interviews, the interviewees were asked to sign an informed consent document, allowing the interviewers to record the conversation for accuracy purposes. The duration of these interviews was between $10 \mathrm{~min}$ and $1 \mathrm{~h}$, and were carried out personally or through voice/video call between March and April 2016. After that, all the interviews were transcribed and coded with the support of the qualitative data analysis software MAXQDA.

\section{Findings}

\subsection{Within-Case Analysis}

STP Case. The main collaboration objective of the STP is to create the means for companies that are in this environment to perform national and international networking activities, as well as to provide specific services to the network members, such as intellectual property and legal support. This is well reflected in the critical knowledge that is shared between network members and in the way they interact with each other. For example, the information channel prioritized is the personal contact and therefore events are realized in a way to guarantee that entrepreneurs can learn with mentors, specialists in intellectual property, investors, etc. The main impacts of this knowledge sharing are related with the own STP's dynamic, mainly in terms of networking and development of business plans. These aspects make sense due to the development stage of startups, i.e. they are starting to develop and grow their businesses, and searching for new investments.

IA1 Case. This IA promotes collaboration within its network through collaborative R\&D projects, by performing two roles: (i) main promoter of $R \& D$ projects by inviting other companies to become project partners; or (ii) stimulator of member's participation in major $R \& D$ projects by disseminating information about $R \& D$ calls and opportunities. It is the understanding of the network manager that the sector represented by this IA is fragmented into several small businesses. Despite having recognized capabilities, their smaller size is perceived as an obstacle to access international value chains. Thus, this IA promotes collaboration as a mean to strengthen the value network capabilities, so that companies are able to deliver higher value added goods and services. Collaboration is accomplished through basic communication channels, such as 
telephone and e-mails. The efforts put forward by this IA have contributed to a regular and consistent presence of network members in the sector's main international fairs and exhibitions, thus providing greater visibility of the sector.

IA2 Case. The collaboration objectives of IA2 are to develop new processes and new products, elaborate $R \& D$ projects and promote the development of joint proposals. Therefore, the critical knowledge shared are the ones created by these collaborations. This is accomplished through Open Days, meetings, and organization and participation in events, such as national and international fairs. The main channel used is the personal contact, through visits and phone calls. Emails, tools for documents sharing, and the website of the IA are also used as the channels for knowledge sharing. All of these bring impacts for the network participants that are measured by the development of new investments and new projects, as well as by the establishment of partnerships.

IA3 Case. This IA promotes the collaboration between the network participants mainly through the use of a collaborative platform and Open Days. This platform is an exclusive channel for the associated companies that allow, for example, an intelligent search to understand the distribution of the different associates within the different markets. With this information, contacts and collaborations are established between the network participants. Regarding the type of critical knowledge shared, IA3 share knowledge about innovation practices and tools for innovation management, as well as some practical knowledge on how to develop $R \& D$ project proposals. The main practice for sharing this knowledge is through collaborative physical workspaces, such as events and conferences, and the channels used are the personal contact and the collaborative platform. From the perspective of this IA, the main impacts of the $\mathrm{CN}$ for the associated companies is the establishment of international contacts, the improvement of innovation capabilities and the public recognition.

\subsection{Cross-Case Analysis}

In order to be effective, KM practices must be related with the organizational strategic objectives [6,33]. This study aims at identifying the collaboration objectives of the analyzed $\mathrm{CNs}$ and to link them to the practices and channels of critical knowledge sharing among network participants that impact their results.

With the cross-case analysis, it was possible to relate the collaboration objectives with the knowledge sharing practices used among the network participants. These collaboration objectives were uniformed and categorized in:

- Create working groups: interactions between different companies that gather together to discuss about strategic decisions;

- Develop business relationships: interactions between different business partners for the purpose of supporting the commercialization of a technology, product, or service;

- Develop new products: interactions towards collaborative product development;

- Develop R\&D projects: interactions towards R\&D projects development; 
- Share intellectual capital: refers to the sharing of relational capital (customers), human (people) and structural (infrastructure, patents, etc.);

- Share technological knowledge: refers to the sharing of information about technologies;

- Share business experiences: refers to the sharing of knowledge on how to conduct business, e.g. information about investors, business plans, product launches, etc.;

- Share information about events: refers to the communications between network members concerning events for customers' prospection, new suppliers, etc.

The Collaborative Physical Workspaces was the knowledge sharing practice identified as the one that supports more collaboration objectives. This practice was not cited for the technological knowledge sharing or information sharing about events. In these cases, the Knowledge Cafes was the one prioritized, which is realized in an informal way by the network participants. Being in a Collaborative Physical Workspace allows to interact with other people through face-to-face communication to talk, discuss or simply ask a question. In well-conceived workspaces, human interactions happen, enabling knowledge sharing and creation [33].

From the collaboration objectives, three types of critical knowledge were identified and categorized as follows:

- Technological knowledge: refers to technological knowledge, scientific knowledge, technological solutions, patents (intellectual property), events about technology, etc.;

- Market knowledge: refers to knowledge about markets, investors and investments, business contacts, business opportunities, etc.;

- Administrative knowledge: refers to business plans, activities management, legal advice, certification, etc.

Table 2 relates the critical knowledge types and the channels for knowledge sharing used among network participants of the analyzed CNs.

In the analyzed STP, three types of critical knowledge were identified, which are mainly shared through personal interaction. This contact and interaction between network participants is facilitated by being in the same physical environment. Events and social networks were also cited as information channels to share knowledge.

Regarding the IAs, participants of IA1 and IA2 also share the three types of critical knowledge, using different channels. In the sectorial IA1, network participants use not only information and communication technologies (e.g. cloud, knowledge repositories, emails, and VOIP) to share both market and technological knowledge, but also the personal contact to share administrative knowledge. In the case of the multi-sectorial IA2 that has predefined technology providers and end-users, besides the channels supported by technology, critical knowledge (of all types) is shared through personal contact in meetings and events. Finally, in the multi-sectorial IA3 that does not have pre-defined end-users within the network, critical market and technological knowledge is shared with the support of a collaborative platform, but also using emails, phone and personal contact.

Table 3 summarizes the collaboration forms and the impacts of knowledge sharing for the organizational results of the network participants. In IAs, the impacts of 
Table 2. Critical knowledge and channels for knowledge sharing

\begin{tabular}{|c|c|c|}
\hline $\mathrm{CN}$ & Critical knowledge & Channels for knowledge sharing \\
\hline \multirow[t]{3}{*}{ STP } & Administrative knowledge & $\begin{array}{l}\text { People, social networks, events, } \\
\text { emails, internet and VOIP }\end{array}$ \\
\hline & Market knowledge & $\begin{array}{l}\text { People, social networks, VOIP, } \\
\text { emails, events and web site }\end{array}$ \\
\hline & Technological knowledge & $\begin{array}{l}\text { Emails, social networks, internet, } \\
\text { events, people and VOIP }\end{array}$ \\
\hline \multirow[t]{3}{*}{ IA1 } & Administrative knowledge & People \\
\hline & Technological knowledge & $\begin{array}{l}\text { Emails, cloud and knowledge } \\
\text { repositories }\end{array}$ \\
\hline & Market knowledge & Videoconference, emails and VOIP \\
\hline IA2 & $\begin{array}{l}\text { Administrative knowledge, Market } \\
\text { knowledge and Technological knowledge }\end{array}$ & People, cloud, emails and web site \\
\hline \multirow[t]{2}{*}{ IA3 } & Market knowledge & $\begin{array}{l}\text { Collaborative platform, phone and } \\
\text { emails }\end{array}$ \\
\hline & Technological knowledge & $\begin{array}{l}\text { Collaborative platform, events, } \\
\text { people, phone and emails }\end{array}$ \\
\hline
\end{tabular}

knowledge sharing are related with continuous improvement, technology development and increased product portfolio, attracting new projects, and increased knowledge base. This last one is much more evident in participants such as industrial associations and researcher institutes, rather than associated companies, which the main collaboration objective is to develop $\mathrm{R} \& \mathrm{D}$ projects. The process of continuous improvement

Table 3. Impacts of knowledge sharing for organizational results

\begin{tabular}{|c|c|c|c|}
\hline $\mathrm{CN}$ & $\begin{array}{l}\text { Organization } \\
\text { type }\end{array}$ & Collaboration objectives & Impacts for organizational results \\
\hline \multirow[t]{6}{*}{ STP } & Startup & $\begin{array}{l}\text { Share technological } \\
\text { knowledge Share } \\
\text { information about } \\
\text { events }\end{array}$ & New investments in business \\
\hline & Startup & $\begin{array}{l}\text { Share business } \\
\text { experiences }\end{array}$ & $\begin{array}{l}\text { Creation of opportunities and } \\
\text { visibility. New investments in } \\
\text { business }\end{array}$ \\
\hline & Startup & $\begin{array}{l}\text { Develop business } \\
\text { relationships }\end{array}$ & $\begin{array}{l}\text { New investments in business. } \\
\text { Increased knowledge base. } \\
\text { Increased networking }\end{array}$ \\
\hline & Pre-incubated & $\begin{array}{l}\text { Share business } \\
\text { experiences }\end{array}$ & $\begin{array}{l}\text { Business plan development. Increased } \\
\text { networking }\end{array}$ \\
\hline & Pre-incubated & $\begin{array}{l}\text { Share business } \\
\text { experiences }\end{array}$ & $\begin{array}{l}\text { Customer acquisition. Increased } \\
\text { networking }\end{array}$ \\
\hline & Pre-incubated & $\begin{array}{c}\text { Share business } \\
\text { experiences }\end{array}$ & Business plan development \\
\hline
\end{tabular}

(Continued) 
Table 3. (Continued)

\begin{tabular}{|c|c|c|c|}
\hline $\mathrm{CN}$ & $\begin{array}{l}\text { Organization } \\
\text { type }\end{array}$ & Collaboration objectives & Impacts for organizational results \\
\hline \multirow[t]{2}{*}{ IA1 } & Company & $\begin{array}{l}\text { Develop business } \\
\text { relationships }\end{array}$ & $\begin{array}{l}\text { Increased number of contracts. } \\
\text { Increased networking }\end{array}$ \\
\hline & $\begin{array}{l}\text { Research } \\
\text { institute }\end{array}$ & Develop R\&D projects & Attracting new projects \\
\hline \multirow[t]{5}{*}{ IA2 } & Company & Develop new products & $\begin{array}{l}\text { Increased product portfolio. } \\
\text { Continuous improvement }\end{array}$ \\
\hline & Association & Develop R\&D projects & Increased knowledge base \\
\hline & Association & $\begin{array}{l}\text { Develop R\&D projects } \\
\text { Share business } \\
\text { experiences }\end{array}$ & Increased knowledge base \\
\hline & Company & $\begin{array}{l}\text { Develop R\&D projects } \\
\text { Create working groups } \\
\text { Share intellectual capital }\end{array}$ & $\begin{array}{l}\text { Continuous improvement. Increased } \\
\text { knowledge base. Costs reduction. } \\
\text { Increased networking }\end{array}$ \\
\hline & Company & $\begin{array}{l}\text { Develop new products } \\
\text { Develop R\&D projects }\end{array}$ & $\begin{array}{l}\text { Technology development. Increased } \\
\text { networking }\end{array}$ \\
\hline \multirow[t]{2}{*}{ IA3 } & Company & $\begin{array}{l}\text { Develop business } \\
\text { relationships Develop } \\
\text { new products }\end{array}$ & Customer acquisition \\
\hline & Company & $\begin{array}{l}\text { Develop new products } \\
\text { Create working groups }\end{array}$ & $\begin{array}{l}\text { Increased networking. Continuous } \\
\text { improvement }\end{array}$ \\
\hline
\end{tabular}

mentioned by the participants is related with improvements in processes and technologies for the product development. Regarding the STP, in both pre-incubated and startups, the main impacts of being connected with the network are related with increased networking, business plan development, new investments in business, creation of opportunities and visibility. This result is very consistent and aligned with the main collaboration objective stated by the participants of sharing business experience.

\section{Discussion}

Socialization among different companies, both in the STP and IAs, is beneficial to the knowledge transfer, as it represents a strategy for sharing tacit knowledge within the group [36] and for increasing the knowledge base about markets, technologies and businesses. Besides this, it was clear that other results were experienced by the participants, such as increased number of contracts, contacts, and product portfolio, driven not only by the formal participation in these CNs but often also through the informal interaction with other network participants. Particularly, the benefits for companies is that a conversation between people can be the start for the development of trust, which is a critical factor to promote creativity [36].

According to Hansson [7], learning in organizations was mainly connected to acquire new knowledge about technical problems and their solutions, not knowledge 
for continuous learning and creativity. Moreover, this knowledge was most of the times managed by an isolated set of processes within the closed boundaries of an organization. However, specifically in the case of the analyzed STP, it became evident that interactions between network participants was facilitated by the formal events, but in addition to this practice, informal meetings or coffee hours are socialization practices cited as those that create better dynamics for knowledge sharing. There is a knowledge and experience sharing that are facilitated by being under the same physical space. Peña [37] state that these business incubation centers (STP in this case) offer a unique setting to develop an important relational capital element, where entrepreneurs overcome together some difficult moments regarding firms' gestation periods.

In IAs, there is evidence about the existence of physical workspaces of interaction that facilitate the knowledge sharing process. The events such as the Open Days have as main objectives to find solutions for a problem of a specific company or to identify innovative solutions for the routine activities of this company. For example, through these events, companies from the network "open their doors" for the other associates. During the event, a company presents its main constraints, needs and trends for the future, in terms of the level of its production processes and technologies. It is also carried out a visit to its facilities, where the invited associated companies present their solutions, which are jointly discussed or are presented individually to the organizing company. Regarding the collaboration objectives and the impacts in the organizational results, in IAs it is much more related with the process of product development and research process. In general, IAs articulates strategies and activities for the common benefit.

\section{Conclusion}

Sharing is the systematic exchange of knowledge between people, facilitated by the use of technologies or by face-to-face interactions. Results show that technologies such as websites, emails and VOIP are used in all analyzed CNs for information and knowledge sharing. Moreover, a collaborative platform is used in IA3. However, in this latter case there is a low adherence and acceptance from the network members due to the fact that they already use other applications and tools that replace the use of a platform, for example, intranet, task managers, etc. Interviewees suggest that this kind of collaborative platforms can have a great impact in their results but it must be considered as a means to reach an end, not as an end in itself. It is necessary to have face-to-face meetings, hear the companies and motivate them, i.e. meet their business needs.

An effective process of knowledge sharing, represented in this study by the collaborative physical workspaces, provides the creation of new knowledge, sharing of experiences and knowledge base increasing about businesses, markets and technologies. Results of this study show that the collaboration is facilitated by the formal process of participation in the network, but it seems that the informal and face-to-face interactions bring better results and more impacts in the companies' activities. Open Days was the knowledge sharing practice identified as one new form of socialization that can be practiced by other types of networks and that can contribute to the development of the KM area. 
This paper has also practical relevance for innovation network managers and participants by allowing the decision-makers, for example, to verify the practices that occur informally and that can be implemented in the network, improving the knowledge sharing process. In the case of the STP, the Knowledge Café that happens informally within the participants can be intensified by understanding the need for formal and informal situations, allowing entrepreneurs to share experiences and know-how. In this kind of environments, results showed that the tacit knowledge sharing has impact in business development.

Empirical evidence has also shown the importance of physical workspaces in facilitating knowledge management practices. Future research could focus on the trade-off between knowledge dispersion and its assimilation, in other words, how knowledge from outside of the typical areas of actuation of organizations can be assimilated towards enlarging their knowledge base, when compared to the knowledge that is shared with the nearest neighbors.

This paper has some natural limitations. The adopted methodological approach is qualitative in nature where it is difficult to obtain a generalization of the results. The objective of this kind of research is not to generalize the results but the main value is the specific description, related to the particularity of a specific context. Therefore, the main contribution of this paper was in understanding the knowledge sharing practices adopted in CNs with the specific context of IAs and STPs, aspect not well explored in previous research.

Acknowledgments. This work was conducted during a scholarship supported by the Doctoral Sandwich Abroad Program CAPES/PDSE at the Federal University of Santa Catarina. Financed by CAPES - Higher Education Personnel Improvement Coordination within the Ministry of Education of Brazil. Additionally, this research was funded by the Portuguese funding agency, Fundação para a Ciência e a Tecnologia (FCT), through the Ph.D. Studentship SFRH/BD/ 110131/2015. It was also supported by the Project "TEC4Growth - Pervasive Intelligence, Enhancers and Proofs of Concept with Industrial Impact/NORTE-01-0145-FEDER-000020" financed by the North Portugal Regional Operational Programme (NORTE 2020), under the PORTUGAL 2020 Partnership Agreement, and through the European Regional Development Fund (ERDF).

\section{References}

1. Ratinho, T., Henriques, E.: The role of science parks and business incubators in converging countries: evidence from Portugal. Technovation 30, 278-290 (2010)

2. OECD: Managing national innovation systems. Paris (1999)

3. Hansson, F., Husted, K., Vestergaard, J.: Second generation science parks: from structural holes jockeys to social capital catalysts of the knowledge society. Technovation 25, 10391049 (2005)

4. Díez-Vial, I., Fernández-Olmos, M.: Knowledge spillovers in science and technology parks: how can firms benefit most? J. Technol. Transf. 40, 70-84 (2015)

5. Wang, X., Kopfer, H., Gendreau, M.: Operational transportation planning of freight forwarding companies in horizontal coalitions. Eur. J. Oper. Res. 237, 1133-1141 (2014) 
6. Dalkir, K.: Knowledge management in theory and practice. Routledge, Abingdon-on-Thames (2013)

7. Hansson, F.: Science parks as knowledge organizations - the "ba" in action? Eur. J. Innov. Manag. 10, 348-366 (2007)

8. Wong, K.: Critical success factors for implementing knowledge management in small and medium enterprises. Ind. Manag. Data Syst. 105, 261-279 (2005)

9. Desouza, K., Awazu, Y.: Knowledge management at SMEs: five peculiarities. J. Knowl. Manag. 10, 32-43 (2006)

10. Balestrin, A., Vargas, L., Fayard, P.: Criação de conhecimento nas redes de cooperação interorganizacional. RAE-revista Adm. Empres. 45, 52-64 (2005)

11. Narteh, B.: Knowledge transfer in developed-developing country interfirm collaborations: a conceptual framework. J. Knowl. Manag. 12, 78-91 (2008)

12. Costa, E., Soares, A.L., Sousa, J.P.: A new insight in the SMEs internationalization process. In: 16th IFIP WG 5.5 Working Conference on Virtual Enterprises, PRO-VE 2015 (2015)

13. Vallejos, R., Gomes, J., Lima, C., Nesello, P.: Combining collaborative networks and knowledge management: the SENAI case. In: 15th IFIP WG 5.5 Working Conference on Virtual Enterprises, PRO-VE 2014 (2014)

14. Soares, A., Alves, F.: Collaborative spaces as mediators for information sharing in collaborative networks. In: 13th IFIP WG 5.5 Working Conference on Virtual Enterprises, PRO-VE 2012 (2012)

15. Widen, G.: Social capital and knowledge sharing: lessons learned. In: 12th IFIP WG 5.5 Working Conference on Virtual Enterprises, PRO-VE 2011 (2011)

16. Buzon, L., Bouras, A., Ouzrout, Y.: Knowledge exchange in a supply chain context. In: 5th IFIP WG 5.5 Working Conference on Virtual Enterprises, PRO-VE 2004 (2004)

17. Camarinha-Matos, L., Afsarmanesh, H.: Concept of collaboration. In: Encyclopedia of Networked and Virtual Organizations, pp. 311-315 (2008)

18. Carneiro, L.M., Soares, A.L., Patrício, R., Azevedo, A.L., de Pinho Sousa, J.: Case studies on collaboration, technology and performance factors in business networks. Int. J. Comput. Integr. Manuf. 26, 101-116 (2013)

19. Cao, M., Zhang, Q.: Supply chain collaboration: impact on collaborative advantage and firm performance. J. Oper. Manag. 29, 163-180 (2011)

20. Romero, D., Galeano, N., Molina, A.: Mechanisms for assessing and enhancing organisations' readiness for collaboration in collaborative networks. Int. J. Prod. Res. 47, 4691-4710 (2009)

21. Parung, J., Bititci, U.: A metric for collaborative networks. Bus. Process Manag. J. 14, 654674 (2008)

22. Camarinha-Matos, L., Afsarmanesh, H.: Collaborative networks: a new scientific discipline. J. Intell. Manuf. 16, 439-452 (2005)

23. Bennett, R.: Business associations and their potential contribution to the competitiveness of SMEs. Entrep. Reg. Dev. 10, 243-260 (1998)

24. Bell, S.: A victim of its own success: internationalization, neoliberalism, and organizational involution at the business council of Australia. Polit. Soc. 34, 543-570 (2006)

25. Link, A., Scott, J.: The economics of university research parks. Oxford Rev. Econ. Policy. 23, 661-674 (2007)

26. Davenport, S., Davies, J., Grimes, C.: Collaborative research programmes: building trust from difference. Technovation 19, 31-40 (1998)

27. Kuo, F., Young, M.: A study of the intention: action gap in knowledge sharing practices. J. Am. Soc. Inf. Sci. Technol. 59, 1224-1237 (2008) 
28. van den Hooff, B., De Ridder, J.: Knowledge sharing in context: the influence of organizational commitment, communication climate and CMC use on knowledge sharing. J. Knowl. Manag. 8, 117-130 (2004)

29. Cohen, W., Levinthal, D.: Absorptive capacity: a new perspective on learning and innovation. Adm. Sci. Q. 35, 128-152 (1990)

30. Bhatt, G.: Knowledge management in organizations: examining the interaction between technologies, techniques, and people. J. Knowl. Manag. 5, 68-75 (2001)

31. Cormican, K., Dooley, L.: Knowledge sharing in a collaborative networked environment. J. Inf. Knowl. Manag. 6, 105-114 (2007)

32. Huang, S., Cummings, J.N.: When critical knowledge is most critical: centralization in knowledge-intensive teams. Small Gr. Res. 42, 669-699 (2011)

33. APO: Knowledge management tools and techniques manual. Asian Productivity Organization. Tokyo, Japan (2010)

34. Yin, R.K.: Case study research: design and methods (2009)

35. Merriam, S.B.: Qualitative Research and Case Study Applications in Education. Jossey-Bass Publishers, San Francisco (1998)

36. Handzic, M., Chaimungkalanont, M.: Enhancing organizational creativity through socialization. Electron. J. Knowl. Manag. 2, 57-64 (2004)

37. Peña, I.: Intellectual capital and business start-up success. J. Intellect. Cap. 3, 180-198 (2002) 